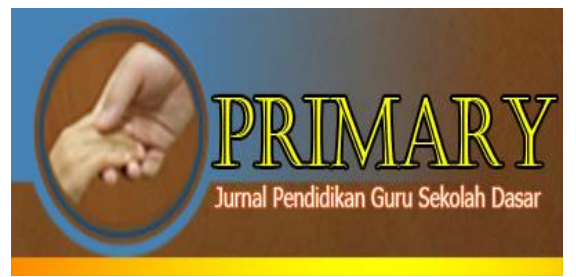

\author{
PRIMARY: JURNAL PENDIDIKAN GURU SEKOLAH DASAR \\ VOLUME 10 NOMOR 3 JUNI 2021 \\ ISSN : 2303-1514 | E-ISSN : 2598-5949 \\ DOI : http://dx.doi.org/10.33578/jpfkip.v10i3.8266 \\ https://primary.ejournal.unri.ac.id/index.php/JPFKIP
}

\title{
IMPLEMENTING THINK PAIR SQUARE LEARNING TECHNIQUE ON STUDENTS LEARNING OUTCOME
}

\author{
Intan Kartika Sari ${ }^{1 *}$, Ardi Yulis ${ }^{2}$, Awalina Barokah ${ }^{3}$, Eva Astuti Mulyani ${ }^{4}$ \\ ${ }^{1}$ Universitas Riau, Pekanbaru, Indonesia \\ ${ }^{2}$ Universitas Islam Negeri Sultan Syarif Kasim Riau, Pekanbaru, Indonesia \\ ${ }^{3}$ Universitas Pelita Bangsa Cikarang, Jawa Barat, Indonesia \\ ${ }^{4}$ Universitas Riau, Pekanbaru, Indonesia \\ *intan.kartika@lecturer.unri.ac.id
}

\section{PENERAPAN TEKNIK PEMBELAJARAN THINK PAIR SQUARE UNTUK MENINGKATKAN HASIL BELAJAR SISWA}

\begin{tabular}{|c|c|}
\hline ARTICLE HISTORY & ABSTRACT \\
\hline $\begin{array}{l}\text { Submitted: } \\
\text { 01 April } 2021 \\
\text { 01 April } 2020\end{array}$ & $\begin{array}{l}\text { Abstract: This research aimed to find out that the implementation of think pair square to } \\
\text { improve students' learning outcome. This was a classroom action research. The data } \\
\text { analysis technique used in this research is qualitative and quantitative data analysis. The } \\
\text { results showed that there was an increase in student learning outcomes from before the } \\
\text { action, cycle I, and cycle II. Before the action only } 9 \text { students }(56,25 \%) \text { achieved the } \\
\text { KKM, in cycle I increased to } 11 \text { students }(68,75 \%) \text { achieved the KKM, and In cycle II } \\
\text { increased to } 14 \text { students (87.50\%) achieved the KKM. Thus it can be concluded that the } \\
\text { application of think pair square learning technique can improve students' learning } \\
\text { outcomes. }\end{array}$ \\
\hline
\end{tabular}

Keywords: cooperative learning, think pair square, learning outcome.

Accepted:

09 April 2021

09 ${ }^{\text {th }}$ April 2021

Published:

22 Juni 2021

$22^{\text {th }}$ June 2021

\begin{abstract}
Abstrak: Penelitian ini bertujuan untuk mengetahui bahwa penerapan think pair square dapat meningkatkan hasil belajar siswa. Penelitian ini merupakan penelitian tindakan kelas. Teknik analisis data yang digunakan dalam penelitian ini adalah analisis data kualitatif dan kuantitatif. Hasil penelitian menunjukkan bahwa terdapat peningkatan hasil belajar siswa dari sebelum tindakan, siklus I, dan siklus II. Sebelum tindakan hanya 9 siswa (56,25\%) yang mencapai KKM, pada siklus I meningkat menjadi 11 siswa (68,75\%) yang mencapai KKM, dan pada siklus II meningkat menjadi 14 siswa (87,50\%) yang mencapai KKM. Dengan demikian dapat disimpulkan bahwa penerapan teknik pembelajaran think pair square dapat meningkatkan hasil belajar siswa.
\end{abstract}

Kata Kunci: pembelajaran kooperatif, teknik pembelajaran think pair square, hasil belajar.

\section{CITATION}

Sari, I. K., Yulis, A., Barokah, A., \& Mulyani, E. A. (2021). Implementing Think Pair Square Learning Technique on Students Learning Outcome. Primary: Jurnal Pendidikan $\begin{array}{llll}\text { Guru Sekolah Dasar, } 10 & \text { (3), 485-493. DOI: }\end{array}$ http://dx.doi.org/10.33578/jpfkip.v10i3.8266.

\section{PENDAHULUAN}

Pendidikan merupakan salah satu cara yang ditempuh seseorang untuk meraih dan mencapai suatu perubahan kearah yang lebih baik yang bersifat menumbuh, mengembangkan dan membentuk kemampuan (potensi) anak. Pendidikan sangatlah penting, tanpa pendidikan manusia akan sulit berkembang bahkan akan semakin terbelakang. Peranan pendidikan harus diarahkan untuk 
menghasilkan manusia yang berkualitas dan mampu bersaing.

Berbagai upaya perlu dilakukan untuk mewujudkan tujuan pendidikan, agar mutu dan kualitas pendidikan meningkat. Upaya yang dilakukan pemerintah untuk meningkatkan mutu dan kualitas pendidikan diantaranya dengan melakukan pengembangan kurikulum. Kurikulum merupakan acuan dalam pelaksanaan kegiatan pembelajaran.

Salah satu mata pelajaran yang diberikan pada jenjang pendidikan dasar adalah matematika. Menurut Anthony \& Walshaw (2009), Secara luas matematika adalah ilmu yang memainkan peranan penting dalam pembentukan individu dalam menghadapi berbagai aspek kehidupan yaitu kehidupan pribadi, sosial dan masyarakat. Lebih lanjut, Mulyani (2020) menjelaskan bahwa siswa dituntut untuk menguasai matematika dan mengembangkan sikap positif agar siswa memiliki pengetahuan yang luas sehingga dapat mencapai tujuan pendidikan.

Kegiatan yang dilakukan dalam pembelajaran matematika agar pembelajaran bermakna yaitu mengamati, menanya, mencoba, menalar, menyaji, dan mencipta. Tujuan pembelajaran matematika menurut Kurikulum 2013 (2013) menekankan pada dimensi pedagogik modern dalam pembelajaran, yaitu menggunakan pendekatan scientific (ilmiah). yaitu (1) meningkatkan kemampuan intelektual, khususnya kemampuan tingkat tinggi siswa, (2) membentuk kemampuan siswa dalam menyelesaikan suatu masalah secara sistematik, (3) memperoleh hasil belajar yang tinggi, (4) melatih siswa dalam mengkomunikasikan ide-ide, khususnya dalam menulis karya ilmiah, dan (5) mengembangkan karakter siswa. Tujuan pembelajaran matematika tingkat SD/MI adalah agar siswa mengenal angka-angka sederhana, operasi hitung sederhana, pengukuran, dan bidang.

Semua faktor yang mempengaruhi pembelajaran matematika perlu ditangani dengan baik agar mencapai tujuan pembelajaran matematika tersebut. Sanjaya (2010) menyebutkan, dalam pelaksanaan pembelajaran ada beberapa faktor yang memiliki peranan penting, diantaranya faktor guru, siswa, sarana, alat dan media yang tersedia, serta faktor lingkungan. Dari faktorfaktor yang telah disebutkan yang menjadi komponen utama penentu keberhasilan pembelajaran adalah faktor guru. Sebagai penentu keberhasilan maka seorang guru hendaknya dapat mengajar dengan menguasai materi, merencanakan pembelajaran dan pengelolaan kelas dengan menggunakan metode yang tepat dalam memberikan pengajaran kepada siswa. Penggunaan metode yang kurang bervariasi dan inovasi akan menimbulkan kebosanan, kurang minat, dan kepasifan dalam pembelajaran. Hal ini tentu akan mengakibatkan rendahnya hasil belajar siswa. Hasil observasi awal peneliti pada pra siklus, diketahui bahwa hasil belajar siswa masih banyak yang di bawah KKM yaitu ratarata 74.5 sedangkan KKM dari mata pelajaran matematika, yaitu 75. Hampir sekitar $43.75 \%$ atau 7 siswa dari 16 siswa mengalami kesulitan belajar.

Banyak pendapat para ahli mengenai pengertian hasil belajar, berikut akan dipaparkan beberapa diantaranya. Hasil belajar merupakan faktor yang penting dalam pendidikan. secara umum hasil belajar selalu di pandang sebagai perwujudan nilai yang diperoleh siswa melalui proses pembelajaran. setelah proses pembelajaran berlangsung, guru selalu mengadakan evaluasi terhadap siswa dengan tujuan untuk mengetahui tingkat penguasaan siswa terhadap materi yang diajarkan. Hasil evaluasi merupakan hasil belajar siswa dalam pembelajaran.

Menurut Djamarah (2006), hasil belajar merupakan akibat dari kegiatan belajar, yang menjadi hasil penilaian pendidikan tentang kemajuan setelah melakukan aktivitas belajar. Hal senada juga diungkapkan oleh Sudjana (2009), hasil belajar merupakan kemampuan yang dimiliki siswa setelah menerima pengalaman belajarnya. Purwanto 
(2009) menunjukkan bahwa hasil belajar adalah pencapaian tujuan pendidikan pada siswa yang mengikuti proses belajar mengajar. Tidak jauh berbeda Anderson, et al (2005) menyatakan bahwa hasil belajar adalah konsekuensi atau hasil yang terkait dengan pengalaman instruksional.

Hasil belajar adalah kemampuankemampuan yang dimiliki siswa setelah ia menerima pengalaman belajarnya. Dalam proses belajar mengajar hasil belajar kognitif lebih dominan dibandingkan dengan hasil belajar bidang afektif dan psikomotor. Meskipun demikian, bukan berarti bidang afektif dan psikomotor diabaikan. Bidang kognitif berkaitan dengan kemampuan siswa dalam penguasaan pembelajaran, maka hasil belajar matematika siswa dapat didefinisikan sebagai suatu kemampuan kognitif yang dimiliki siswa setelah proses pembelajaran yang berupa skor atau nilai dari tes yang dilaksanakan diakhir pembelajaran.

Dengan demikian hasil belajar pada penelitian ini adalah hasil atau nilai yang dicapai siswa melalui kegiatan pembelajaran dan pengukuran dalam bentuk angka-angka setelah siswa diberikan tes atau kuis. Jadi hasil belajar matematika adalah output yang dicapai berkat adanya proses pembelajaran matematika.

Indikator siswa yang hasil belajarnya bagus adalah: (1) siswa dapat menguasai materi, sehingga hampir seluruh siswa mampu menyelesaikan soal-soal. (2) skor yang diperoleh siswa mencapai standar yang telah ditentukan sekolah. (3) siswa dapat mengerjakan soal yang bervariasi. (4) siswa mengerjakan pekerjaan rumahya dengan baik.

Sekarang ini, matematika masih menjadi mata pelajaran yang dianggap sulit bagi sebagian besar siswa. Matematika merupakan mata pelajaran yang bersifat abstrak, cenderung sulit diterima dan dipahami oleh siswa. Oleh karena itu diperlukan kreativitas seorang guru untuk merancang pembelajaran agar menarik dan memudahkan siswa dalam memahami pembelajaran. Siswa juga seharusnya berinteraksi multi arah baik bersama guru maupun siswa lainnya.

Salah satu alternatif yang dapat dilakukan oleh seorang guru guna menjawab permasalahan pembelajaran tersebut serta untuk lebih mengaktifkan pembelajaran di kelas adalah dengan menerapkan teknik pembelajaran think pair square. Menurut Isjoni (2011) teknik pembelajaran think pair square termasuk salah satu teknik pembelajaran kooperatif yang merupakan pengembangan dari think pair share (Frank Lyman). Teknik ini memberi siswa kesempatan untuk bekerja sendiri serta bekerja sama dengan orang lain. Menurut Lie (2007), keunggulan lain dari dari teknik ini adalah optimalisasi partisipasi siswa. Dengan metode klasikal yang memungkinkan hanya satu siswa maju dan membagikan hasilnya untuk seluruh kelas, teknik think pair square ini memberi kesempatan sedikitnya delapan kali lebih banyak kepada setiap siswa untuk dikenali dan menunjukkan partisipasi mereka kepada orang lain. Teknik ini bisa digunakan dalam semua mata pelajaran dan untuk semua tingkatan usia anak didik.

Adapun langkah-langkah pembelajaran dengan menggunakan teknik pembelajaran think pair square adalah sebagai berikut: (1) guru membagi siswa kedalam kelompok yang terdiri dari 4 orang dengan pengelompokan heterogen berdasarkan kemampuan akademiknya dan jenis kelaminnya. (2) guru memberikan LKS kepada masing-masing siswa. (3) setiap siswa dalam kelompok berempat memikirkan dan mengerjakan tugas masing-masing. (4) siswa berpasangan dengan salah satu rekan dalam kelompok berempat dan berdiskusi mengenai materi. (5) kedua pasangan kembali dalam kelompok untuk membagikan hasil kerjanya. (6) guru berkeliling memeriksa jalannya kegiatan. (7) setiap kelompok mengumpulkan hasil diskusinya. (8) siswa bersama guru memeriksa hasil diskusi.

\section{METODE PENELITIAN}


Subjek dalam penelitian ini adalah seluruh siswa kelas V di salah satu sekolah dasar Kabupaten Kampar yang berjumlah 16 siswa. Penelitian ini merupakan penelitian tindakan kelas (PTK) atau yang sering disebut dengan classroom action research yang dilaksanakan selama dua siklus. Arikunto, dkk (2008) menjelaskan tahapan pelaksanaan penelitian tindakan kelas, yaitu perencanaan, tindakan, pengamatan, dan refleksi.

Penelitian ini bertujuan untuk mengetahui peningkatan hasil belajar siswa setelah menggunakan teknik pembelajaran think pair square. Teknik pengumpulan data yang digunakan adalah observasi, tes, dan dokumentasi. Dalam penelitian ini observasi bertujuan untuk mengumpulkan informasi mengenai proses pembelajaran matematika di kelas. Dokumentasi untuk memperoleh gambaran jelas mengenai kegiatan pembelajaran di kelas menggunakan teknik pembelajaran think pair square. Sedangkan tes digunakan untuk mengetahui peningkatan hasil belajar siswa setelah menggunakan teknik pembelajaran think pair square pada pembelajaran matematika.

Teknik analisis data yang digunakan dalam penelitian ini adalah analisis data kualitatif dan kuantitatif. Analisis data kualitatif digunakan untuk menganalisis lembar observasi, aktivitas siswa dan guru, lembar keterlaksanaan teknik pembelajaran. Sedangkan analisis data kuantitatif digunakan untuk mengukur hasil belajar siswa melalui tes. Untuk mengukur tes hasil belajar tersebut menggunakan skor penilaian, rata-rata kelas, prersentase ketuntasan belajar, penialaian akhir siswa, kriteria nilai yang dicapai siswa, keberhasilan belajar siswa dan keterlaksanaan teknik pembelajaran yang digunakan.

\section{HASIL DAN PEMBAHASAN}

Sebelum melaksanakan penelitian, sebagai tahap awal peneliti mengadakan diskusi dengan guru kelas tentang keadaan siswa pada tahun-tahun sebelumnya. Hasil diskusi ini antara lain: para siswa kurang termotivasi dalam mengikuti pembelajaran, kurang dalam pemahaman konsep, belum diterapkannya belajar berkelompok, siswa yang belum mengerti malu mengacungkan tangan untuk bertanya. Setelah kegiatan refleksi awal peneliti bersama guru matematika mendiskusikan kemungkinan tindakan yang dapat dilakukan untuk mengatasi masalah yang dihadapi siswa. Dalam pertemuan tersebut disepakati menerapkan tindakan berupa implementasi pendekatan kontekstual melalui teknik pembelajaran think pair square.

Penerapan teknik pembelajaran think pair square untuk meningkatkan hasil belajar matematika kelas V dilaksanakan selama 2 siklus yaitu siklus I dan II, masing-masing siklus terdiri dari 2 pertemuan. Data hasil observasi keterlaksanaan penerapan teknik pembelajaran think pair square terdapat dalam tabel 1 berikut:

Tabel 1. Aktivitas guru dan siswa dengan penerapan teknik pembelajaran think pair square

\begin{tabular}{|c|c|c|c|}
\hline & & Guru & Siswa \\
\hline \multirow{3}{*}{$\begin{array}{l}\text { Siklus } \\
\text { I }\end{array}$} & Rata-rata & 27 & 72 \\
\hline & Presentase & $82,82 \%$ & $64,3 \%$ \\
\hline & Kategori & Baik & Cukup Baik \\
\hline \multirow{3}{*}{$\begin{array}{c}\text { Siklus } \\
\text { II }\end{array}$} & Rata-rata & 29 & 89 \\
\hline & Presentase & $90,63 \%$ & $79,5 \%$ \\
\hline & Kategori & Baik & Baik \\
\hline
\end{tabular}

Berdasarkan tabel 1, dapat diketahui hasil rata-rata observasi guru pada siklus I sebesar 27 atau $82,82 \%$ termasuk pada kategori baik. Pada siklus II mengalami peningkatan menjadi 29 dengan persentase 90,63 \% dalam kategori baik, dari hasil tersebut diketahui pelaksanaan oleh guru telah mencapai hasil yang sangat baik dan mencapai indikator pencapaian yang diharapkan yaitu $\geq 75 \%$.

Di sisi lain, hasil observasi terhadap siswa dengan langkah-langkah yang menggunakan penerapan teknik pembelajaran think pair square untuk meningkatkan hasil belajar matematika implementasi mengalami peningkatan pada siklus I, skor hasil observasi 
sebesar 72 atau $64,3 \%$ dengan kategori cukup, pada siklus II mengalami peningkatan menjadi 89 atau 79,5\% dengan kategori baik. Langkahlangkah yang tepat dan dinyatakan berhasil mencapai indikator pencapaian yang diharapkan yaitu $\geq 75 \%$. Gambaran peningkatan pada setiap siklusnya dapat dilihat pada diagram berikut:

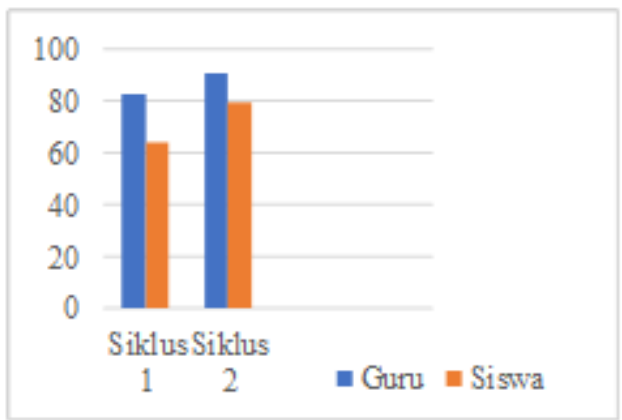

Gambar 1. Peningkatan Keterlaksanaan Penerapan teknik pembelajaran think pair square

Berdasarkan tabel 1 dan gambar 1 diketahui bahwa pada siklus I penerapan teknik pembelajaran think pair square masih belum optimal. Setelah dilakukan refleksi berdasarkan hasil observasi maka diketahui bahwa dalam pelaksanaan diskusi kelompok belum berlangsung optimal. Pada tiap-tiap kelompok masih tampak lebih mengutamakan penonjolan individu. Hal ini tampak dari anggota kelompok yang lebih suka mengerjakan ke depan kelas sebelum membantu pemahaman teman di kelompoknya. Untuk mengatasi ini guru berulang-ulang memberitahukan agar soal-soal yang diberikan didiskusikan dulu dalam kelompoknya dan jika ada siswa yang belum mengerti agar bertanya kepada teman sekelompoknya.

Berdasarkan hasil refleksi pada siklus I, maka ada beberapa hal yang perlu diperbaiki oleh guru dalam penerapan teknik pembelajaran think pair square pada siklus II. Pada siklus II penerapan teknik pembelajaran think pair square, sudah lebih baik dari pada siklus I. Pada siklus II diskusi kelompok berjalan dengan baik. Anggota kelompok yang sudah mengerti mau memberi penjelasan kepada teman dikelompoknya yang belum mengerti dan yang belum mengerti tidak malumalu menanyakan kepada teman sekelompoknya. Bahkan siswa berani bertanya kepada guru bila semua anggota kelompoknya belum yakin dengan terhadap hasil diskusinya. Bila disuruh ke depan kelas hampir semua siswa mengacungkan tangan, walaupun setelah ditunjuk ke depan ada yang jawabannya salah. Ini berarti siswa sudah berani mengemukakan pendapatnya tidak peduli salah atau benar. Pada siklus II, guru memberikan bimbingan lebih kepada siswa yang nilainya kurang pada siklus I.

Aktivitas Guru dan siswa dalam penerapan teknik pembelajaran think pair square mengalami peningkatan yang signifikan dari siklus I ke siklus II, hal ini disebabkan guru dan siswa telah melaksanakan langkah-langkah teknik pembelajaran think pair square dengan baik.

Teknik pembelajaran think pair square diterapkan pada pembelajaran matematika dengan langkah-langkah: 1) guru membagi siswa kedalam kelompok yang terdiri dari empat orang dengan pengelompokkan heterogen berdasarkan kemampuan akademiknya dan jenis kelaminnya, 2) guru memberikan LKS kepada maisng-masing siswa, 3) setiap siswa dalam kelompok berempat memikirkan dan mengerjakan tugas masing-masing, 4) siswa berpasangan dengan salah satu rekan dalam kelompok berempat dan berdiskusi mengenai materi, 5) guru berkeliling memeriksa jalannya kegiatan, 6) setiap kelompok mengumpulkan hasil diskusinya dan 7) siswa bersama guru memeriksa hasil diskusi.

Langkah-langkah teknik pembelajaran think pair square yang diterapkan sudah disesuai dengan langkah-langkah teknik pembelajaran think pair square yang dijelaskan oleh Anita Lie (2007), yaitu: 
a. Guru membagi siswa dalam kelompok berempat dan memberikan tugas kepada semua kelompok.

b. Setiap siswa memikirkan dan mengerjakan tugas tersebut sendiri.

c. Siswa berpasangan dengan salah satu rekan dalam kelompok dan berdiskusi dengan pasangannya.

d. Kedua pasangan bertemu kembali dalam kelompok berempat.

Tujuan penerapan teknik pembelajaran think pair square pada pembelajaran matematika adalah untuk meningkatkan hasil belajar, oleh karena itu setelah pembelajaran pada setiap pertemuan selesai, peneliti membagikan tes hasil belajar sebagai intrumen untuk mengukur hasil belajar. Selain itu dengan bantuan para observer dan teman sejawat, menggunakan instrumen lembar observasi untuk menilai ketepatan penerapan teknik pembelajaran think pair square pada pembelajaran matematika. Hasil belajar siswa mengalami peningkatan pada setiap pertemuannya. Berikut adalah data hasil penelitian yang merupakan hasil olah tes hasil belajar yang telah diberikan oleh guru kepada siswa pada setiap pertemuan dan setiap siklus.

Tabel 2. Peningkatan Hasil Belajar Siswa

\begin{tabular}{cccc} 
Siklus & Siswa & Presentase & Kategori \\
\hline $\begin{array}{c}\text { Pra } \\
\text { siklus }\end{array}$ & 9 & $56,25 \%$ & $\begin{array}{c}\text { Belum } \\
\text { Tuntas }\end{array}$ \\
\hline I & 11 & $68,75 \%$ & $\begin{array}{c}\text { Belum } \\
\text { Tuntas }\end{array}$ \\
\hline II & 14 & $87,50 \%$ & Tuntas \\
\hline
\end{tabular}

Tampak pada tabel 2 bahwa setelah dilakukan tindakan penerapan teknik pembelajaran berempat berpasangan hasil belajar siswa meningkat di setiap siklusnya.

Berdasarkan hasil belajar siswa pada setiap akhir pertemuan, diperoleh hasil pada prasiklus siswa yang tuntas berada dalam persentase $56,25 \%$, sedangkan pada siklus I siswa yang tuntas berada dalam persentase $68,75 \%$, untuk siklus II ketuntasan hasil belajar siswa dalam persentase 87,50 \% sehingga dianggap telah melampaui indikator keberhasilan penelitian yaitu $\geq 75 \%$. Peningkatan hasil belajar siswa di setiap siklusnya dapat digambarkan melalui diagram berikut:

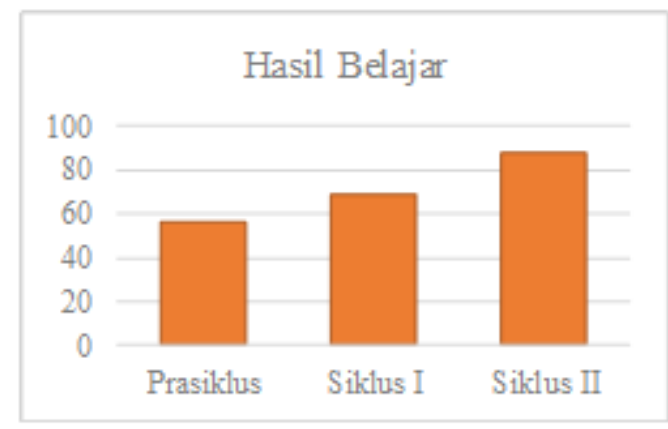

Gambar 2. Peningkatan Hasil Belajar Siswa

Dari gambar 2 di atas, tampak bahwa hasil belajar siswa mengalami peningkatan pada setiap siklusnya setelah pembelajaran matematika didesain dengan menerapkan pendekatan penerapan teknik pembelajaran berpikir berpasangan. Dengan demikian, dapat disimpulkan bahwa teknik pembelajaran think pair square dapat meningkatkan hasil belajar siswa.

Teknik pembelajaran think pair square merupakan salah satu teknik pembelajaran kooperatif. Pembelajaran kooperatif merupakan strategi pembelajaran yang di dalamnya mengkondisikan para siswa untuk bekerja bersama-sama di dalam kelompokkelompok kecil untuk saling membantu satu sama lain dalam belajar. Hal ini sejalan dengan pendapat Arends \& Kilcher (2010) yang menyatakan bahwa pembelajaran kooperatif adalah model pembelajaran atau strategi yang dicirikan oleh tugas kelompok, tujuan, dan struktur penghargaan, dan membutuhkan siswa untuk secara aktif terlibat dalam diskusi, debat, latihan, dan kerja sama tim. Selain itu, Slavin (2006) menyebutkan pembelajaran kooperatif merupakan pendekatan pembelajaran dimana 
siswa bekerja dalam kelompok-kelompok kecil dengan kemampuan yang beragam.

Dari pendapat di atas dapat disimpulkan bahwa pembelajaran kooperatif adalah suatu model pembelajaran yang memanfaatkan kerja sama dalam kelompok-kelompok, dimana keberhasilan kelompok ditentukan oleh keaktifan dari masing-masing anggota kelompok. Dalam kegiatan kooperatif tiap anggota kelompok saling membantu dan mendorong temannya agar berhasil dalam belajar. Keberhasilan belajar menurut model ini bukan semata-mata ditentukan oleh kemampuan individu secara utuh melainkan perolehan belajar itu semakin baik apabila dilakukan bersama dalam kelompok kelompok kecil yang terstruktur dengan baik. Melalui proses belajar dari teman sebaya di bawah bimbingan guru, maka proses penerimaan dan pemahaman semakin mudah dan cepat terhadap materi yang dipelajari. Hal senada juga di ungkapkan oleh Asakawa, et al (2016) keberhasilan pelaksanaan pembelajaran kooperatif harus memperhatikan empat prinsip, yaitu saling ketergantungan positif, tanggung jawab individu, kesempatan yang sama untuk berpartisipasi, dan interaksi dengan rekan.

Teknik pembelajaran think pair square telah terbukti mampu meningkatkan hasil belajar siswa. Hal ini didukung juga oleh penelitian terdahulu yang dilakukan oleh Lasiyanto (2018), hasil penelitiannya menunjukkan bahwa model pembelajaran ini dapat meningkatkan minat dan prestasi belajar matematika. Pada tahun yang sama, Irianti \& Wijaya (2018) memperoleh kesimpulan bahwa penerapan think pair square dalam pembelajaran mampu meningkatkan aktivitas dan prestasi belajar siswa. Berikutnya penelitian eksperimen yang dilakukan oleh Antika, dkk (2019), tentang pengaruh penerapan model pembelajaran kooperatif tipe think-pair-square terhadap kemampuan pemahaman matematis ditinjau dari kemampuan awal matematika siswa, dimana terdapat perbedaan kemampuan pemahaman konsep matematis siswa antara siswa yang diajar dengan model pembelajaran think pair square dengan siswa yang diajar dengan pembelajaran konvensional. Penelitian selanjutnya dilakukan oleh Irianto (2020) tentang peningkatan sikap percaya diri dan prestasi belajar matematika melalui model pembelajaran kooperatif tipe think pair square. Berdasarkan data penelitian tindakan kelas diperoleh hasil bahwa penerapan model pembelajaran think pair square dapat meningkatkan sikap percaya diri dan prestasi belajar matematika.

\section{KESIMPULAN}

Penerapan teknik pembelajaran think pair square pada pembelajaran matematika dengan langkah-langkah : 1) guru membagi siswa kedalam kelompok yang terdiri dari 4 orang dengan pengelompokkan heterogen berdasarkan kemampuan akademiknya dan jenis kelaminnya, 2) guru memberikan LKS kepada maisng-masing siswa, 3) setiap siswa dalam kelompok berempat memikirkan dan mengerjakan tugas masing-maisng, 4) siswa berpasangan dengan salah satu rekan dalam kelompok berempat dan berdiskusi mengenai materi, 5) guru berkeliling memeriksa jalannya kegiatan, 6) setiap kelompok mengumpulkan hasil diskusinya dan 7) siswa bersama guru memeriksa hasil diskusi.

Penerapan teknik pembelajaran berpasangan berempat terlihat dalam peningkatan aktivitas guru dan siswa. Pada siklus I aktivitas guru tergolong "Baik", dengan persentase $82.82 \%$, dan siklus II meningkat menjadi $90.63 \%$ tergolong "Baik". Persentase aktivitas siswa siklus I adalah 64.3\% atau tergolong "Cukup", dan siklus II meningkat menjadi $79.5 \%$ atau tergolong "baik". Meningkatnya aktivitas guru dan siswa sangat berpengaruh terhadap hasil belajar siswa.

Peningkatan hasil belajar siswa juga terlihat pada prasiklus ketuntasan siswa hanya mencapai 9 orang (56.25\%), dan 7 orang siswa $(43.75 \%)$ belum tuntas. Setelah tindakan siklus I ketuntasan belajar siswa meningkat menjadi 
11 orang siswa $(68.75 \%)$, dan 5 orang siswa $(31.25 \%)$ belum tuntas. Siklus II ketuntasan siswa mencapai $88.89 \%$ atau sekitar 14 orang siswa yang telah mencapai nilai KKM yang ditetapkan, yaitu 60. Dengan demikian, teknik pembelajaran think pair square dapat meningkatkan hasil belajar matematika siswa.

Berdasarkan simpulan di atas, maka dikemukakan saran-saran berikut (a) disarankan kepada guru matematika kelas $\mathrm{V}$ SD untuk mencoba menerapkan teknik pembelajaran think pair square dengan banyak memberi kesempatan kepada siswa untuk berdiskusi dalam kelompoknya dan guru membimbing siswa dalam pembelajaran tersebut agar tercipta suasana kelas yang kondusif, (b) disarankan kepada peneliti lain untuk mengembangkan model pembelajaran diatas dan mencobanya di jenjang pendidikan yang lebih tinggi.

\section{DAFTAR PUSTAKA}

Anderson, H. M., Moore, D. L., Anaya, G., \& Bird, E. (2005). Student learning outcomes assessment: A component of program assessment. In American Journal of Pharmaceutical Education (Vol. 69, Issue 2, pp. 256-268). https://doi.org/10.5688/aj690239

Anthony, G., \& Walshaw, M. (2009). Characteristics of Effective Teaching of Mathematics: A View from the West. Journal of Mathematics Education, 2(2), 147-164.

Antika, M. S., Andriani, L., \& Revita, R. (2019). Pengaruh Penerapan Model Pembelajaran Kooperatif Tipe ThinkPair-Square terhadap Kemampuan Pemahaman Konsep Matematis Ditinjau dari Kemampuan Awal Matematika Siswa SMP. JURING (Journal for Research in Mathematics Learning), 2(2),

118. https://doi.org/10.24014/juring.v2i2.7553.

Arends, R. I., \& Kilcher, A. (2010). Teaching for Student Learning: Becoming an Accomplished Teacher. Routledge.
Arikunto, S., Suhardjono, \& Supardi. (2008). Penelitian Tindakan Kelas. Bumi Aksara.

Asakawa, M., Kanamaru, A., Plaza, T., \& Shiramizu, C. (2016). Useful expressions for Implementing Cooperative Learning in English. The Electronic Journal for English as a Second Language, 19(4).

Djamarah, S. B. (2006). Strategi Belajar Mengajar. Rineka Cipta.

Irianti, N. P. \& Wijaya, E. M. S. (2018). ThinkPair-Square (TPS), Sebuah Model Pembelajaran Kooperatif dalam Meningkatkan Aktivitas dan Prestasi Belajar Siswa. Inteligensi : Jurnal Ilmu Pendidikan, 1(1), 17-22. https://doi.org/10.33366/ilg.v1i1.1139.

Irianto, S. (2020). Peningkatan Sikap Percaya Diri dan Prestasi Belajar Matematika Melalui Model Pembelajaran Kooperatif Tipe Think Pair Square. Jurnal JSSH, 4(1).

http://jurnalnasional.ump.ac.id/index.php/JS SH/article/view/5715

Isjoni. (2011). Cooperative Learning Mengembangkan Kemampuan Belajar Berkelompok. Alfabeta.

Kemendikbud. (2013). Kerangka Dasar dan Struktur Kurikulum 2013. Kemendikbud.

Lasiyanto. (2018). Penerapan teknik penugasan dengan metode think pair square untuk meningkatkan minat dan prestasi belajar matematika siswa dalam pembelajaran matematika. Jurnal Wiyata Dharma: Jurnal Penelitian Dan Evaluasi Pendidikan, 6(1), 15-19.

Lie, A. (2007). Cooperative Learning. PT. Grasindo.

Mulyani, E. A., Kasdianti, A., Ain, S. Q., Alim, J. A., Sari, I. K., \& Alpusari, M. (2020). Correlation between Elementary School Students' Mathematics SelfEfficacy and Motivation. Journal of Teaching and Learning in Elementary 


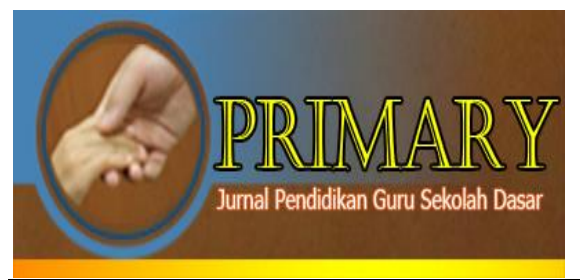

\section{PRIMARY: JURNAL PENDIDIKAN GURU SEKOLAH DASAR \\ VOLUME 10 NOMOR 3 JUNI 2021 \\ ISSN : 2303-1514 | E-ISSN : 2598-5949 \\ DOI : http://dx.doi.org/10.33578/jpfkip.v10i3.8266 \\ https://primary.ejournal.unri.ac.id/index.php/JPFKIP}

Education (JTLEE), 3(1).

https://doi.org/10.33578/jtlee.v3i1.7831

Purwanto. (2009). Evaluasi Hasil Belajar. Pustaka Pelajar.

Sanjaya, W. (2010). Strategi Pembelajararan Berorientasi Standar Proses Pendidikan. Kencana.

Slavin, R. E. (2006). Educational Psychology: Theory and Practice (8th ed.). Pearson Education, Inc.

Sudjana, N. (2009). Penilaian Hasil Proses Belajar Mengajar. PT Remaja Rosdakarya. 